\title{
Methodology and practice of organizing work on extremism prevention at regional level (experience of Sverdlovsk region)
}

\author{
Nazarov Vladimir Lazarevich \\ $\mathrm{PhD}$, Professor of Institute of Physical Culture, Sports and \\ Youth Policy \\ Ural Federal University \\ URFU \\ Yekaterinburg, Russia \\ nazarov@sky.ru
}

\author{
Suslonov Pavel Evgenyevich \\ Consultant of Department of Internal Policy of Governor of \\ Sverdlovsk Region and Government of Sverdlovsk Region, \\ $\mathrm{PhD}$, associate professor of Institute of Physical Culture, \\ Sports and Youth Policy of Ural Federal University \\ URFU \\ Yekaterinburg, Russia \\ dr.suslonow2010@yandex.ru
}

\author{
Kolegova Nadezhda Sergeevna \\ Ural Federal University named after the first President \\ of Russia B.N.Yeltsin, Yekaterinburg \\ student of the 2 th course, master programme \\ URFU \\ Yekaterinburg, Russia \\ kolegova.nadezhda93@gmail.com
}

\begin{abstract}
The article reveals the methodological and practical aspects of the regional system of preventing extremism. It is argued that extremism is a systemic threat to society. The importance of joint efforts of public authorities and civil society institutions to prevent extremist manifestations is underlined. The main activities and results of work on preventing extremism in the region are presented.
\end{abstract}

Keywords - Prevention; extremism; region; interethnic and ethno-confessional relations

Prevention of extremism is one of the most important areas of activity of public authorities both at the federal and regional levels.

With a relatively small number of registered extremist crimes, the government bodies at various levels invariably pay great attention to counteracting extremism, since this type of offense is a systemic threat, which encroaches on the existence of society and the state as a whole, on peace and harmony between various national, religious and social groups of Russian society, on political and legal stability [1]. This is the main danger of extremism. The leaders of the Russian state constantly emphasize the importance of activities in this direction [2].

Federal Law of July 25, 2002 No. 114-FZ "On Countering the Extremist in Art. 2 [3], the priority of measures aimed at preventing extremist activity, as well as the cooperation of the state with public and religious associations, other organizations and citizens in counteracting extremist activity, outlines the main principles of countering extremist activity.

The key role in countering extremism is played not so much by the struggle of law enforcement agencies with extremist crimes, as by the joint efforts of state authorities, local governments and civil society institutions to prevent extremist manifestations among various groups of the population. Law enforcement bodies, in the nature of their activities, deal with an already accomplished fact of the offense and with the offender as the carrier of the formed extremist socio-psychological attitude and outlook. The main thing in the fight against extremism is prevention, prevention of the formation of extremist consciousness and subsequent extremist manifestations.

It is necessary to recognize that the regional level is the key in the national system of preventing extremism, since it is at this level that interaction with local governments and civil society institutions, directly working with the region's population, takes place [4].

The inclusion of representatives of civil society in the process of preventing extremism is especially important for regional authorities. It is fairly noted that for states with insufficiently active civil society and a high level of distrust towards state institutions, the development of technological and information infrastructure threatens to further increase the 
authorities' disbelief, disunity and manifestations of extremism [5].

Modern methodology and culture of public administration is based on strategic analysis and planning, suggesting the identification of different levels of external and internal environment of the system: shortcomings and advantages, threats and opportunities [6].

The content and structure of the system for the prevention of extremism in the youth environment are determined to a large degree by the socio-political environment and the ethnoconfessional situation in the region, its strong and weak tasks.

Historically, the Middle Urals is distinguished by interethnic, multicultural and polyconfessional diversity, while being an example of a tolerant attitude of representatives of ethnic groups and confessions to each other. [7, 8]. Also, Sverdlovsk Region is a region with a high degree of sociopolitical activity [9].

At the same time, the region can identify factors that contribute to the escalation of extremist sentiments, potentially capable of leading to the commission of extremist acts.

Throughout 2016-2017 in Sverdlovsk region, there were no officially recognized interethnic or interreligious conflicts. At the same time, violations, in which the parties to the conflict were representatives of different nationalities, were committed [10].

The main problem with this was the behavior of some representatives of the media, who tried to use the national identity of the participants in conflicts as an informational excuse.

The main threats to the possible complication of the situation in the sphere of ethno-confessional relations on the territory of Sverdlovsk region are, firstly, migration flows from the countries of Central Asia, illegal migration and penetration of the ideology of Islamism with migration flows; Secondly, the organizational fragmentation of the Muslim community (the presence of several centralized Muslim organizations that compete with each other). Especially dangerous is the penetration of the ideology of Islamist religious and political extremism into the youth environment.

In 2016 in Yekaterinburg, a guilty verdict was passed against the leader of one of the Muslim communities. This person was convicted of creating an extremist Islamist community. A significant number of parishioners of this imam were young people who were subjected to intensified Islamist propaganda.

According to the Main Directorate of the Ministry of Internal Affairs of the Russian Federation for Sverdlovsk region, among the extremist crimes registered in the region, the actions connected with the spread of extremist ideology using the Internet are prevalent. In this regard, it remains urgent to address preventive measures to counter extremism, primarily in the educational sphere, in accordance with the
Strategy for the Development of Education in the Russian Federation for the period up to 2025 [11].

Currently, Sverdlovsk region has a significant positive experience in organizing the system of prevention of extremism. This system includes public authorities, local government bodies, civil society institutions. The accumulated experience allows analyzing the grounds, practices, risks and threats, results and achievements in the work on the prevention of various types of extremist manifestations.

Prevention of extremism at the level of state power of the subject of the Federation should be organized within the framework of the system approach - a methodological direction, based on the consideration of the object as a system: a holistic complex of interrelated elements, a set of interacting objects, a set of entities and relationships [12].

A systematic approach to evaluation presupposes a comprehensive analysis of both the phenomenon being studied and the organization of counteraction to this phenomenon or the prevention of its negative manifestations.

Extremism, being by its generic sign a position, inclination, conviction of a political subject, is a complex, multifaceted phenomenon. There are several components in it. First, the ideological and ideological (ideological) aspect is the set of ideological attitudes and political ideas that underlie and legitimize the extremist actions of this subject. Secondly, the psychological (personal-emotional) aspect is mentality, a mental attitude of a special kind that distinguishes the personality of an extremist. Thirdly, the politicalorganizational (practical) aspect - forms and methods of extremist activity as socially significant behavior.

Using the system approach as a methodology, one must consider all possible aspects of the phenomenon that of interest, taking into account the inseparable connection of extremism with other spiritual and socio-political phenomena.

An ideological and world outlook (ideological) component of extremism can be most fully described by the concept of "radicalism". Extremism is the continuation of radicalism. Since radicalism is an aggregate of some bright, unusual, beyond the permissible ideas, it is logical that similar "extreme" means are applicable for their implementation.

Speaking about the ideological and worldview aspect of extremism, as such let us distinguish the radical consciousness, which is carried by the subjects of extremist activity. This consciousness is based on three attitudes: the admissibility and universality of violence as a way of solving socially significant issues, legal nihilism and, as a consequence, disregard for the basic human rights and freedoms, the denial of the absolute value of the individual as such. All other ideological signs of extremism in the scientific literature are derived from the aforesaid. But extremism also contains certain socially attractive attitudes, since it implies a "great goal", a socio-political or religious project, for the implementation of which deconstructive methods are used. 
One more aspect of extremism, singled out by researchers of this phenomenon, is a special psychological warehouse of an individual who carries out or gravitates toward extremist activity. Extremism is not only and not so much a radical idea as a special type and a store of thinking. Extremism is the development and application of radicalism, but not every bearer of radical ideas can realize them in practice.

Turning to the coverage of the political and organizational aspect of extremism, one must determine the basis for identifying the types of extremism, its classification.

The most common basis for classifying extremism is the value basis. Extremist actions presuppose meaning, that is, for the sake of which they are committed. Proceeding from this basis, let us single out religious extremism, ideological (political) extremism and nationalist extremism.

Nationalist extremism is actions or calls for action based on national or racial hatred and enmity, inciting hatred and enmity towards people of a different nationality or race.

Ideological (political) extremism is the theory and practice of violent, illegal capture and retention of state power, acts and appeals to acts aimed at violent change of the constitutional order.

Religious extremism is the practice of forcibly planting religious faith among unbelievers or representatives of other religions, in which both freedom of conscience (the opportunity to be a believer or non-believers) and freedom of religion (the opportunity to choose any religion) are violated the fundamental values of modern society. Tolerance in the religious sphere is respect for the right of another person to a spiritual and philosophical choice.

In modern Russia, including at the regional level, manifestations of these types of extremism are closely intertwined and are often associated in the person of one association or individual.

Speaking about the system approach in the study of the organization of countering extremism, polysubjectiveness of this process should be noted.

The priority of preventive measures in countering extremism was already noted above. Therefore, law enforcement agencies, in the person of the police, security agencies, the prosecutor's office and the judiciary, occupy an important but local place in the overall regional system of countering extremism. This is also due to the fact that law enforcement agencies in the administrative and regulatory legal terms have a federal identity.

In the regional system of countering extremism, the following subjects are singled out.

First, these are the bodies of state power of the corresponding subject of the Federation. In each region of Russia, executive power units have been established and are functioning, including those responsible for implementing programs to counter extremism, monitoring conflict situations in the sphere of interethnic and inter-confessional relations, and socio-political activity of a non-constructive orientation.

Secondly, these are municipal authorities, local selfgovernment bodies responsible for the implementation of municipal programs, and the relevant municipal commissions for the prevention of extremism.

Thirdly, it is the society of the region, civil society, which includes numerous public associations of constructive orientation: political parties, youth, veterans', student organizations, Cossack societies and national-cultural autonomies, traditional religious denominations, and cultural organizations.

Fourthly, these are the educational management bodies, educational organizations of various levels and types, which, in their activities, include the educational component.

Fifthly, these are the above-mentioned law enforcement agencies, primarily the bodies of internal affairs. The most numerous and close to the population are the units for juvenile affairs and district police commissioners. It is the employees of these units, in the nature of their activities, who are faced with manifestations of deviant behavior in the youth environment, including those with extremist character.

Work on the prevention of manifestations of extremism among young people is entrusted, by virtue of its mass character, to employees of the units for juvenile affairs and district police commissioners. Interaction with educational organizations, conducting interviews among students and students, organizing and conducting preventive conversations with minors and their parents, participating in educational seminars and meetings with educators and members of the public require police officers not only to know the relevant normative legal acts, but also to possess pedagogical And psychological skills, knowledge in the field of socio-political and humanitarian disciplines.

Thus, in the Sverdlovsk region, a regional system for countering extremism is being built. But at the same time, any institutional system is inconceivable without an actual regulatory framework. In the field of countering extremism, such a foundation exists both at the federal and regional levels.

At the national level, the Strategy for Countering Extremism in the Russian Federation until 2025 (here in after referred to as the Strategy) was adopted [13].

Within the framework of the Strategy at the regional level, the state programs of the Sverdlovsk region on the historical and cultural education of young citizens, the formation of knowledge of the cultural and historical traditions of Russia and the Urals, the skills of intercultural dialogue, the development of teenage and youth sports centers and places for their intellectual leisure, the support of socially-oriented non-profit Organizations working in the sphere of strengthening the interethnic consent of the peoples living in the Sverdlovsk region. 
A set of measures aimed at improving the work of Sverdlovsk region public authorities in preventing interethnic conflicts, including the creation of effective mechanisms for their settlement and conducting a system monitoring of the state of interethnic and ethno-confessional relations, has been developed and is being implemented.

In the sphere of state national policy in order to implement the federal target program "Strengthening the Unity of the Russian Nation and the Ethno-Cultural Development of the Peoples of Russia (2014-2020)" [14], Sverdlovsk Oblast adopted a comprehensive program "Strengthening the Unity of the Russian Nation and the Ethnic and Cultural Development of the Peoples of Russia, Living in Sverdlovsk region "for 2014 - 2020 [15].

From time immemorial, the Ural is distinguished by interethnic, multicultural and polyconfessional diversity. This is due to the fact that the Ural region is located at the intersection of two world civilizations - Europe and Asia, which determined the universality of the cultural development of the region. The culture of the Urals was originally formed as a multicultural culture, as it represented a joint culture of the peoples of the Finno-Ugric, Turkic and Indo-Iranian communities. At the same time, cultural diversity was complicated by the diversity of the religious picture of the world of the Urals: Orthodox Christian, Sunni Muslim, traditional pagan ... However, despite this, the culture of the Urals is an example of the tolerant attitude of the peoples of the Urals to each other.

Currently, one of the richest in the national composition of the Great Urals is the Middle Urals, politico-territorialized as Sverdlovsk region with a center in the city of Yekaterinburg.

Representatives of more than 160 nationalities live in Sverdlovsk region, with the Middle Urals traditionally being a territory of national peace and harmony. Sverdlovsk region is one of the most polyconfessional regions of the Russian Federation; there are more than 740 religious organizations of 20 religions.

In Sverdlovsk region, all the necessary conditions for the development of spiritual culture, national customs and traditions of the peoples of Urals region are being created. The executive bodies of state power in Sverdlovsk region actively support public associations involved in the work on the development of ethnic cultures and the prevention of extremism. Particular attention is paid to the organization of work on the harmonization of inter-ethnic and interconfessional relations among students in educational and youth organizations.

In Sverdlovsk region, the system of work of government bodies with representatives of national-cultural associations and diasporas has been built. Heads of national-cultural associations are members of the Advisory Council for Nationalities of Sverdlovsk Region. For many years, the socially oriented non-commercial organization "Sverdlovsk Regional Association of Public Associations" "Association of
National and Cultural Associations of Sverdlovsk Region" is active, which includes representatives of national and cultural autonomies and associations of major nationalities living in Sverdlovsk region.

How can one ensure that there is no inter-religious and inter-ethnic enmity and strife in society and in the state? To stop being afraid of someone else, it is necessary to get acquainted with one. It is not necessary to become the same, but at least one has to try to understand and to find common ground with one.

One of the means of harmonizing interethnic relations is the celebration the Day of the peoples of the Middle Urals. Sverdlovsk region became the first region in Russia, where a similar holiday was approved. According to the Decree of the Governor of Sverdlovsk region of September 23, 2002 No. 618-UG "On measures to implement the national policy of Sverdlovsk region", events dedicated to the celebration of the Day of the Middle Urals are held annually, on the first Sunday of September.

Holiday "Day of the peoples of the Middle Urals" gathers representatives of national and cultural societies and autonomies, residents and visitors of Yekaterinburg and the region. The central area for the celebration is the family recreation park "Taganskaya Sloboda". There are 26 ethnotrees (national farmsteads) that allow visitors to be acquainted with the customs and culture of the multinational Urals.

Yekaterinburg residents and guests of the Ural capital can visit Russian, Ukrainian, Belarusian, Bashkir, Udmurt, Mari, Chuvash, Tatar, German, Korean, Armenian, Tajik, Georgian, Azerbaijani, Kazakh, Uzbek, Gypsy, Greek, Jewish, Kurdish, Chechen, Ossetian and the Kyrgyz farmstead. Guests of the holiday can watch the process of making Armenian wine, baking Tajik bread kulcha in tandyr; Georgians showed how the Georgian delicacy from the grape juice and walnuts is prepared. In Russian metochion the guests get acquainted with the famous ritual action of Bratina, participate in the production of Shalinskiy gingerbread, they can ride on Russian and Korean swings and get acquainted with the subtleties of making cedar oil.

National craft shops also work here. The program of festive events included planting seedlings on the improvised "Alley of Nationalities", and the celebration itself was accompanied by performances by creative teams. For the guests of the event, interactive programs on traditional culture of peoples, glades of ethnic music and dances of the peoples of the Urals worked.

In 2016, the regional authorities decided to unite the Day of the Peoples of the Middle Urals and the Spartakiad of the Peoples of the Urals. Also within the framework of the festival was the Spartakiad of the Peoples of the Urals, organized by the Ministry of Physical Culture, Sports and Youth Policy of Sverdlovsk Region in association with the Association of National Cultural Associations. More than 400 amateurs took part in the Games. On this day, there were competitions on 
football, volleyball, national sports - wrestling on belts, kuresh. More than 20 teams took part in the competitions.

Virtually every religion or culture of the people can find universal values and moral precepts. Therefore, when communicating and studying another culture, it is necessary to focus on the general that connects people, as well as to objectively and unbiasedly get acquainted with the peoples and religions as they really are. If a person is well acquainted with the tradition of a people with whom he lives side by side and, at the same time, is familiar with his own tradition, he is unlikely to hate others just because they are different.

The authors believe that the continuation of the tradition of celebrating the Day of the Peoples of the Middle Urals will promote fruitful cooperation in ensuring inter-ethnic and interreligious harmony, promoting common values and promoting intercultural dialogue, strengthening ethno-cultural ties, expanding contacts between citizens' public associations, implementing state programs of the Russian Federation and Sverdlovsk Area and projects in the sphere of national relations

A systematic work is carried out to organize training seminars and events with the involvement of the heads of centralized religious organizations and teachers of educational institutions of theological profile, during which there were presentations of Russian religious and secular educational institutions by the profiles of confessional training.

The Ministry of General and Professional Education of Sverdlovsk Region sends methodological materials on the formation of a culture of tolerance, prevention of extremist crimes in the youth environment to the heads of educational departments and subordinate educational organizations.

In general education organizations, the monitoring of the content filters that prevent access to Internet sites, containing extremist materials, is organized, and the monitoring of incoming materials for their availability in the Federal List of Extremist Materials is conducted.

Methods and technologies for the prevention of extremism are widely discussed at scientific conferences held in the region.

Thus, on December 16, 2016, the Ural State Economic University hosted the international conference "Youth Environment - Territory without Extremism and Terrorism".

On March 31-April 1, 2017, the Ural Federal University together with the Institute for the Development of Education of Sverdlovsk Region for the first time conducted a scientific and practical conference with international participation "Ethno-cultural and interreligious communication in the educational environment. Trends in development and risk management ". At the department "Organization of work with youth", UrFU successfully works on a new master's program "Prevention of extremism in the youth environment. On October 25-26, 2016, on the basis of the University, an international competition of research works of university students was held on the subject "Prevention of Extremism in the Youth Environment". 46 students from 17 universities of Russia, Armenia, Kazakhstan, Kyrgyzstan, Tajikistan and a number of other countries took part there. One of the winners of the contest was the master of new master's program - Putina Olga.

Thus, it can be concluded that in Sverdlovsk Region a sufficiently effective systemic work is carried out to implement all the main directions of the Strategy for Countering Extremism in the Russian Federation. In the region, all the necessary conditions are created for the development of spiritual culture, national customs and traditions of the peoples of the Urals region. The executive bodies of state power and local self-government of Sverdlovsk region provide active support to public associations involved in the work on the development of ethnic cultures and the prevention of extremism. Particular attention is paid to the organization of work on the harmonization of inter-ethnic and inter-confessional relations among students and students in educational and youth organizations.

\section{References}

[1] P. Suslonov " Role and tasks of internal affairs bodies in organizing counteraction to extremist crime in the Russian Federation: monograph Ekaterinburg: Ural Law Institute, Ministry of Internal Affairs of Russia”, p.3,2015.

[2] Speech by President of the Russian Federation at the extended board meeting of the Russian Interior Ministry March 9, 2017. [Electronic resource] - Access mode. - URL: http://www.kremlin.ru/events/preside nt / news // 54014

[3] On Countering Extremist Activity: Federal Law of July 25, 2002 No. 114-FZ // SZ RF. - 2002. - No. 30. - Art. 3031.

[4] V. Nazarov, P. Suslonov "The regional system of preventing extremism in the youth environment: the grounds and practices, risks and results (on the example of the Sverdlovsk region)", Pedagogical education in Russia, vol.7(72),pp. 114 -123, 2017.

[5] N. Dmitrieva, E. Styrin "Open public administration: tasks and prospects in Russia", Issues of state and municipal management, vol. 1, pp. 127 148.

[6] O. Maysak "SWOT-analysis: object, factors, strategies. The problem of finding connections between factors", vol. 1(21) The Caspian Journal: Management and High Technologies, 2013.

[7] G. Kazakova "Formation of the "Ural branch" of the Russian culture: theoretical and methodological approaches to the study", vol.17(22) Vestnik SUSU, pp. 229-232, 2016.

[8] Official website of the Government of the Sverdlovsk region. [Electronic resource] - Access mode. - URL: http://www.midural.com/community/100332/100689/100690

[9] Official site of the Main Directorate of the Ministry of Justice of the Sverdlovsk Region. [Electronic resource] - Access mode. - URL: http://to66.minjust.ru/node/2555

[10] Official site of the Investigative Department of the Investigative Committee of Russia for the Sverdlovsk region. [Electronic resource] Access mode.

URL: http://sverdlovsk.sledcom.ru/Novosti/item/1038993/, http://sverdlovsk.sledcom.ru/Novosti/item/1064558.

[11] The strategy for the development of upbringing in the Russian Federation for the period until 2025 (Order of the Government of the Russian Federation of 29 May 2015 No. 996-p) [Electronic resource] Access mode. - URL: http://www.consultant.ru/document/cons_doc_LAW_180402/ 
[12] I. Blauberg, V.Sadovsky, E. Yudin "System approach", New philosophical encyclopedia,Institute of Philosophy of the Russian Academy of Sciences; Nat. Soc.-nauch. fund; Prev. Scientific ed. Council V. Styopin, deputy predecessors: A. Huseynov, G. Semigin, Sec. A. Ogurtsov. - 2 nd ed., Rev. And add. - M .: Misl, 2010.

[13] Strategy for countering extremism in the Russian Federation until 2025 (Approved by Decree of the President of the Russian Federation No. Pr2752 of 28 November 2014). [Electronic resource] - Access mode. URL: http://legalacts.ru/doc/strategija-protivodeistvija-ekstremizmu-vrossiiskoi-federatsii-do/ (Date of circulation 07/05/2017).

[14] Decree of the Government of the Russian Federation No. 718 of August 20, 2013 "On the Federal Target Program" Strengthening the Unity of the Russian Nation and the Ethnic and Cultural Development of the Peoples of Russia (2014-2020) ". [Electronic resource] - Access mode. URL: http://www.consultant.ru/document/cons_doc_LAW_151043.

[15] Decree of December 24, 2013, No. 1605-PP "On the approval of the comprehensive program of the Sverdlovsk Region" Strengthening the Unity of the Russian Nation and the Ethno-Cultural Development of the Peoples of Russia Living in the Sverdlovsk Region for 2014-2020. " [Electronic resource] - Access mode. - URL: http://sverdlovskgov.ru/doc/110342. 